\title{
Mechanism investigation of virus removal in a membrane bioreactor
}

\author{
X. Zheng ${ }^{* * *}$ and J.X. Liu* \\ ${ }^{\star}$ Research Center for Eco-Environmental Sciences, Chinese Academy of Sciences, Beijing, 100085, P.R. \\ China (E-mail: jxliu@rcees.ac.cn) \\ ${ }^{\star *}$ School of Environment \& Natural Resources, Renmin University of China, Beijing, 100872, P.R. China
}

\begin{abstract}
Virus removal in a membrane bioreactor (MBR) by gravity drain was studied. Coliphage f2 (mean size of $25 \mathrm{~nm}$ ), which is similar in size to human enteric pathogenic viruses, was selected as a model virus. Two microfiltration membrane modules with pore sizes of $0.22 \mu \mathrm{m}$ and $0.1 \mu \mathrm{m}$ were applied to investigate the effects of membrane pore size on the virus rejection. The MBR with these modules could reject virus in a range of 2.6-5.1 logs. The experimental results showed that the mechanisms of virus removal in the MBR involved rejection and inactivation. The virus rejection depended mainly on the dynamic layer on the membrane surface (not membrane itself) because virus rejection by the membrane modules with pore sizes of $0.1 \mu \mathrm{m}$ and $0.22 \mu \mathrm{m}$ were similar. The microbial activity and the aeration oxidation were the two important factors for the virus inactivation. It was found that the inactivation of coliphage $f 2$ was much more rapidly in activated sludge mixed liquor than in clean water, and the effect of aeration was significant.

Keywords Coliphage f2; MBR; virus removal; virus removal mechanism
\end{abstract}

\section{Introduction}

Viral pathogens from wastewater have a potential harm to the environment and human health. Therefore, control of virus has been a major concern in wastewater treatment and water reclamation and reuse. In addition to disinfection, some methods of virus removal combined with wastewater treatment processes were sought (Madaeni, 1995; Salgot et al., 2001; Hu et al., 2003). In a membrane bioreactor (MBR) system, membranes serve as a microbial barrier that can reject most of the biomass in the bioreactor. Therefore, one of the main advantages of an MBR system is to remove a wide range of microorganisms, including Escherichia coli and fecal coliform bacteria. Some studies showed that MBR can be efficient in removal of bacteria (Krauth and Staab, 1993; Gunder and Krauth, 1998; Steven et al., 1998). Recent research work has also showed virus could be removed remarkably by an MBR. For instance, a bench-scale study by Ueda and Horan (Ueda and Horan, 2000) showed that 2-6 log removal of indigenous T-even-like bacteriophage (with a mean size of $200 \mathrm{~nm}$ ) could be achieved by an MBR; however, only $0.91 \mathrm{log}$ removal of the same type of bacteriophages could be achieved by conventional activated sludge processes. Another bench-scale study by Shang et al. (2005) found that removal of bacteriophage MS-2 was through three steps: physical filtration by the membrane itself, biomass activity in the aeration tank, and bio-filtration of the biofilm developed on the membrane surface. Our previous research also showed that the formation of cake layer was the main cause for a high removal rate of coliphage T4 in an MBR with polyvinylidene fluoride (PVDF) membrane of $0.22 \mu \mathrm{m}$ (Zheng et al., 2005). However, very few studies have addressed the mechanism and the effect of microbial activity and operation parameters on the behavior and fate of viruses in MBR systems.

Human enteric pathogenic viruses can enter municipal sewage through discharge of waste from infected persons. Contamination of sewage with viruses may also promote 
disease outbreaks. Enteric viruses may cause severe diseases, such as myocarditis (coxsackievirus), paralysis (polioviruses), meningitis (echovirus), or infectious hepatitis (hepatitis A and E viruses)(Sakoda et al., 1997; Petterson and Ashbolt, 2001; Rzezutka and Cook, 2004). Due to the difficulty in assaying enteric viruses, the coliphage $\mathrm{f} 2$ has thus been suggested as viral indicators because they closely resemble enteric viruses in terms of the structure, morphology, size and behavior (Pesaro et al., 1995). Therefore, coliphage $\mathrm{f} 2$ was selected in this study as a virus tracer to investigate the virus removal mechanism. Two micro-filtration (MF) membrane modules, with the pore sizes of 0.22 and $0.1 \mu \mathrm{m}$, respectively, were used to investigate the remove of coliphage f2 in the MBR. The objectives of this study were to: (1) evaluate the efficacy of MBR for virus removal; (2) compare the virus rejection of the two membrane modules; (3) evaluate the effect of relative parameters on the virus rejection; and (4) propose possible mechanism of virus removal in an MBR.

\section{Materials and methods}

\section{MBR system}

An MBR with gravity drain was used in this study (Figure 1), and its operating parameters are listed in Table 1. The bioreactor was an air-lift reactor, and two hollow-fiber membrane modules with the mean pore sizes of 0.22 and $0.1 \mu \mathrm{m}$ were installed in the downside, respectively. The membrane flux was driven by the pressure-head between the liquid level in the bioreactor and the effluent pipe. Compressed air was supplied from the bottom of the modules, and the membrane surfaces were cleaned by air scouring. The MBR was continuously operated by the gravity drain under a given pressure head.

\section{Operating procedures}

The MBR had been operated successfully for a period of 66 days prior to this study. In the first 13 days, cultured coliphage f2 was added to the influent. Later, coliphage f2 was fed to the bioreactor intermittently on 13th, 32nd, 54th days to study the inactivation of coliphage f2. No excess sludge was discharged from the MBR. The operational

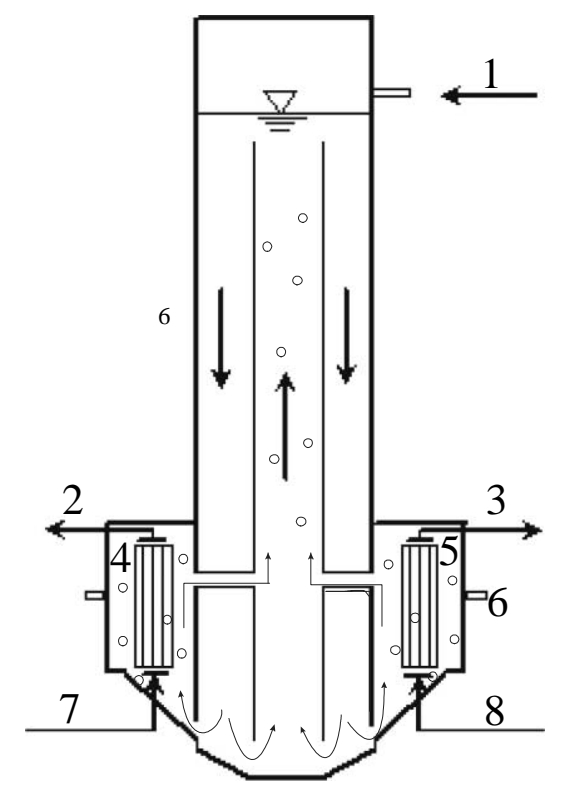

Figure 1 The schematic diagram of the MBR: 1 Influent; 2, 3 Effluent; 4 Module(0.1 $\mu \mathrm{m})$; 
Table 1 Character of the membrane modules

\begin{tabular}{lcc}
\hline Item & Module 1 & Module 2 \\
\hline Membrane Materials & polyvinylidene fluoride (PVDF) & Polypropylene (PP) \\
Membrane area $\left(\mathrm{m}^{2}\right)$ & 0.18 & 0.18 \\
Pore size $(\mu \mathrm{m})$ & 0.22 & 0.1 \\
Diameter inner/outer $(\mathrm{mm})$ & $0.5 / 0.8$ & $0.35 / 0.45$ \\
\hline
\end{tabular}

parameters are listed in Table 2. After 66 days of operation, the membrane modules were immersed in the solutions of $0.7 \%$ sodium hydroxide and $2 \%$ sodium hypochlorite for 12 hours to damage the dynamic layer on the membrane fibers. Then, tap water enriched with a given concentration of coliphage $\mathrm{f} 2$ was fed to the MBR and continuous operation was resumed under aerated and non-aerated conditions to study the inactivation of coliphage $\mathrm{f} 2$ under a clean water feeding condition.

\section{Analytical methods}

Concentrations of the infective $\mathrm{f} 2$ particles were determined by the plaque forming unit (PFU) assay, using the double agar overlay (DAL) method and E.coli 285 as the host. Coliphages and host bacteria were purchased from Institute of Hygiene and Environmental Medicine, Academy of Military Medical Sciences of China. Suspended solids (SS) and volatile suspended solids (VSS) were determined according to Standard Methods. The $\mathrm{pH}$ was measured with a $\mathrm{pH}$ meter (pHS-3C, China). Dissolved oxygen (DO) and temperature were measured with a portable DO meter combined with a temperature probe (JBP-607 DO, China).

\section{Preparation for coliphage f2}

The culture media for E.coli 285 comprised: peptone $10 \mathrm{~g} / \mathrm{L}$, beef extract $3 \mathrm{~g} / \mathrm{L}$, and sodium chloride $5 \mathrm{~g} / \mathrm{L}$ at buffered $\mathrm{pH}$ 7. The top soft layer and the bottom rigid layer contained agar of 8 and $15 \mathrm{~g} / \mathrm{L}$, respectively. The media were autoclaved at $121^{\circ} \mathrm{C}$ for 20 minutes before use. The preparation for coliphage was as follows: a loop of coliphage $\mathrm{f} 2$ was seeded in a flask containing a culture media of E. coli 285 which had been incubated at $37^{\circ} \mathrm{C}$ for 12 hours to ensure growth of the bacterium. The flask was then continuously shaken at $37^{\circ} \mathrm{C}$ for another few hours to complete cell lysis. Thereafter, the flask was supplied with some culture media that had incubated for 6 hours to obtain young E.coli 285 cells so as to enhance the titer of the coliphages, and was then shaken until another complete lysis was completed. The lysate was collected and centrifuged at $2500 \mathrm{rpm}$ for 10 minutes. The supernatant was added to sewage water to make the coliphage concentration in a range from $10^{5}$ to $10^{8} \mathrm{PFU} / \mathrm{mL}$.

\section{Extract f $\mathbf{2}$ from activated sludge}

Desorption of coliphages from activated sludge samples was carried out as follows. The activated sludge samples were clarified by centrifugation at $4000 \mathrm{rpm}$ for $10 \mathrm{~min}$. Supernatant fluids contained the non-adsorbed virus particles. The precipitate was rinsed three times by the EDTA-Gly buffer solution ( $0.05 \mathrm{~mol} / \mathrm{L}$ EDTA, $0.25 \mathrm{~mol} / \mathrm{L}$ Gly, $\mathrm{pH}=9.5)$. Extraction medium was added and the mixture was shaken gently at room temperature for $10 \mathrm{~min}$. It was confirmed separately that $10 \mathrm{~min}$ was long enough to reach the

Table 2 Operating parameters

\begin{tabular}{ccccr}
\hline & T/ ${ }^{\circ} \mathbf{C}$ & pH & HRT/h & MLSS/g.L-1 \\
\hline Range & $14-25$ & $5.8-8.1$ & $3.5-21$ & $4.9-12.6$ \\
\hline
\end{tabular}


desorbed equilibrium. The adhered virus from activated sludge samples were washed out by the procedure. The eluant was adjusted to $\mathrm{pH} 7.2$ and numbers of released viral particles were determined by the plaque assay.

\section{Evaluation of retention data}

Three samples were taken from the influent, supernatant liquid and effluent. The supernatant was obtained by centrifuging a sample of mixed liquor from the MBR at $4000 \mathrm{rpm}$ for $10 \mathrm{~min}$ to remove suspended solids. The purpose of measuring the sample of supernatant was to distinguish virus removal between adsorption by the activated sludge and the rejection by the membrane (including the dynamic layer accumulated on the membrane surface). Thus, the difference in the virus concentration between the influent and the effluent represents the virus removal by the MBR system, and that between the supernatant and the effluent represents the virus rejection by membrane. The retention of $\mathrm{f} 2$ was calculated with Equations 1 and 2:

$$
\begin{aligned}
\mathrm{LRV} & =\log C_{\text {in }} / C_{\text {out }} \\
\mathrm{LRV}_{\mathrm{m}} & =\log C_{\text {super }} / C_{\text {out }}
\end{aligned}
$$

where LRV is the virus removal in the MBR system, $L R V_{m}$ is the virus rejection by the membrane, and $C_{\text {in }}, C_{\text {super }}$ and $C_{\text {out }}$ are the virus concentrations in the influent, supernatant liquid and effluent, respectively.

\section{Results and discussion}

Virus removal in MBR system

Removal of coliphage f 2 varied from 0.3 to 5.3 logs during the 10 week operation of the MBR. The virus concentrations in the permeates of the two different membrane modules (the PP and PVDF membranes) were shown in Figure 2a. The results showed that they had a similar rejection trend, although their mean pore sizes were 0.1 and $0.22 \mu \mathrm{m}$, respectively. Figure $2 b$ depicted the virus $L_{R V}$ for the two membrane modules. During the stable operation, both PP and PVDF membranes provided the virus rejection of 2.0-5.1 logs.

\section{Statistical analysis of membrane rejection}

In order to investigate the parameters related to the membrane rejection, statistical analysis including Pearson and Spearman's rank correlation was carried out (see Table 3). The results showed that the virus concentrations in the supernatant significantly affected that in the effluents $(\alpha=0.01)$ and the virus rejection by the membrane $(\alpha=0.05)$.
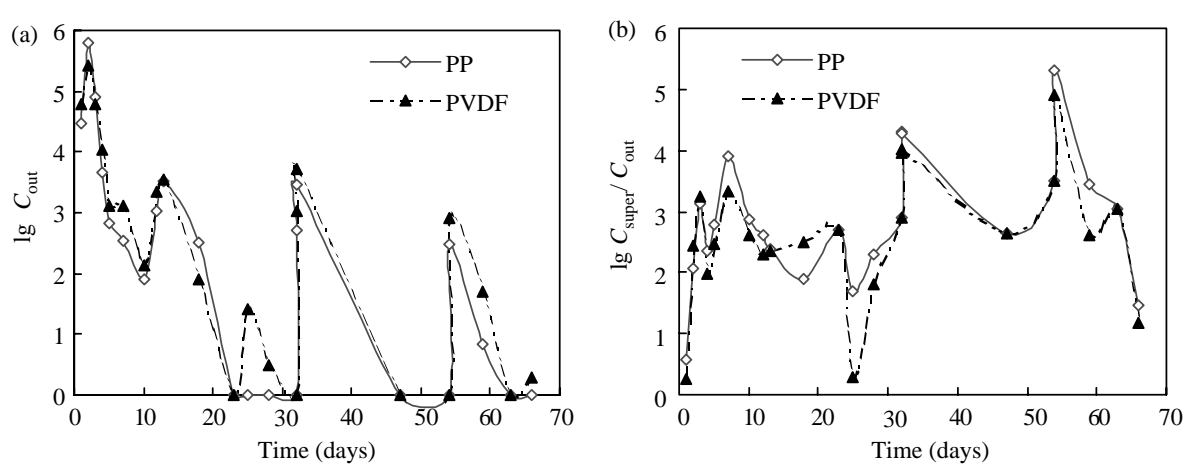

Figure 2 Virus removal in the MBR system, (a) coliphage level in the permeates (b) total coliphage rejection by the membranes 
Table 3 Correlations between parameters and virus rejection

\begin{tabular}{|c|c|c|c|}
\hline & $c_{\text {in }}$ & $C_{\text {super }}$ & $R / m^{-1}$ \\
\hline \multicolumn{4}{|c|}{ PVDF membrane rejection } \\
\hline Min & $5.0 \lg$ & $1.5 \lg$ & $5.2 \times 10^{11}$ \\
\hline Max & $7.8 \lg$ & $8.0 \lg$ & $8.8 \times 10^{12}$ \\
\hline \multicolumn{4}{|c|}{ Pearson correlations } \\
\hline$C_{\text {out }}$ & .515 & $.836^{\star \star}$ & -.346 \\
\hline LRVm & .598 & $.493^{\star}$ & $.772^{\star \star}$ \\
\hline \multicolumn{4}{|c|}{ Spearman's rank correlations } \\
\hline$C_{\text {out }}$ & .264 & $.794^{\star \star}$ & $-.613^{\star}$ \\
\hline LRVm & .567 & .382 & $.865^{\star \star}$ \\
\hline \multicolumn{4}{|c|}{$P P$ membrane rejection } \\
\hline Min & $5.0 \lg$ & $1.5 \lg$ & $1.7 \times 10^{12}$ \\
\hline Max & $7.8 \lg$ & $8.0 \mathrm{lg}$ & $2.1 \times 10^{13}$ \\
\hline \multicolumn{4}{|c|}{ Pearson correlations } \\
\hline$C_{\text {out }}$ & .570 & $.847^{\star \star}$ & -.430 \\
\hline LRVm & .408 & $.438^{\star}$ & $.885^{\star \star}$ \\
\hline \multicolumn{4}{|c|}{ Spearman's rank correlations } \\
\hline$C_{\text {out }}$ & .296 & $.831^{\star \star}$ & -.523 \\
\hline LRVm & .381 & .399 & $.688^{\star \star}$ \\
\hline
\end{tabular}

${ }^{* \star}$ Correlation is significant at the 0.01 level (2-tailed)

${ }^{*}$ Correlation is significant at the 0.05 level (2-tailed)

Besides, the membrane fouling also affected the virus rejection $(\alpha=0.01)$. Therefore, the impact of membrane fouling as well as the virus concentrations was further investigated.

\section{Membrane fouling on virus rejection}

The formation of the dynamic layer can be divided into the two stages: a cake layer at the beginning of filtration and a gel layer. In general, the membrane fouling is attributed to initial pore blocking followed cake formation. The formation of the cake layer is a dynamic process, which is determined entirely by the hydrodynamic characteristic of the system. It decreases in thickness when turbulence is promoted. In this test system, a good hydrodynamic environment and adequate shear over the membrane surface were provided by high aeration intensity. The cake layer on the membrane surface has been found to reach a dynamic equilibrium under constant cross flow conditions in a short time (Figure 3a). To investigate the impact of the membrane fouling on the rejection of virus at different stages, five virus samples were taken within the first $120 \mathrm{~h}$ and after this one sample was taken per three to five days. The extent of membrane fouling was monitored during the sampling.

Variations of virus concentrations in the influent, supernatant and effluent are presented in Figure 3b. It is clear that accumulation of virus in the supernatant did not occur in spite of the continuous injection of coliphage $\mathrm{f} 2$ into the reactor.

Figure $3 \mathrm{c}$ showed the virus removal in the first 120 hours in the MBR system at a MLSS of $4.8 \mathrm{~g} \cdot \mathrm{L}^{-1}$. The initial removal of virus by the PVDF and PP membranes was about 0.3 and $0.6 \mathrm{logs}$, respectively, because the two membranes were new and the cake layer on the membrane surface was not formed. After this, the virus removal increased rapidly with the operation time. Over $2.3 \log$ removal by the PVDF membrane was observed in the 18th hour, and about 3.0 log removal was achieved after 115 hours. Variations of membrane resistance and the virus removal showed that the formation of a cake layer resulted in further rejection of virus and an increase in the LRV (Figure 3).

Such a pattern of the virus removal may be explained by the different rejection mechanisms that are typically attributed to MF membranes. When the membrane is clean, 

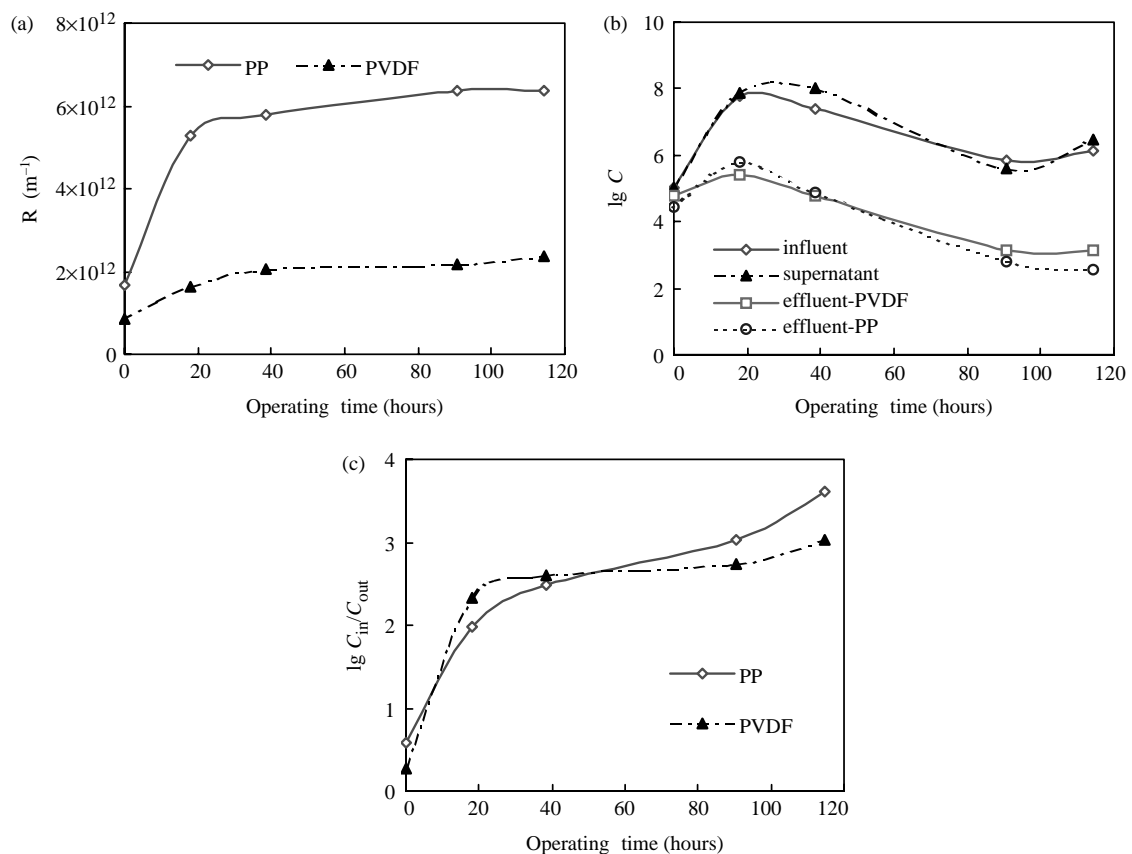

Figure 3 The test results within the first $120 \mathrm{~h}$. (a) Filtration resistance in the MBR; (b) the virus levels; (c) total virus removal in the MBR system

virus rejection is mainly size sieving of the membrane pores. In this mechanism, the retention of the membranes is related to their pore sizes. When a cake layer is formed on the membrane surface, the dominant mechanism for virus removal becomes interception by the cake layer.

At the beginning of filtration, the presence of extra cellular substances in the supernatant could be negligible low so that a steady deposition and accumulations are likely to occur. In the following stage, the organic solutes rejected by MF membrane leads to the formation of a gel layer, which may have greater selectivity and lower permeability than the membrane itself. The formation of the gel layer leads to the accumulation of the suspended matter at the membrane surface to form a dynamic layer. There are a rapid increase in the filtration resistance and a decrease in the cake porosity due to cake compression. The variation of the $\mathrm{LRV}_{\mathrm{m}}$ at different membrane resistances is shown in Figure 4. When membrane resistance of PVDF increased from $2.1 \times 10^{12}$ to $8.8 \times 10^{12}$ (Figure 4a), the $\mathrm{LRV}_{\mathrm{m}}$ increased sharply from 3.2 to 4.9 logs under the near-constant virus concentration of $7.9 \pm 0.1 \log$ in the supernatant (Figure 4b). However, the virus
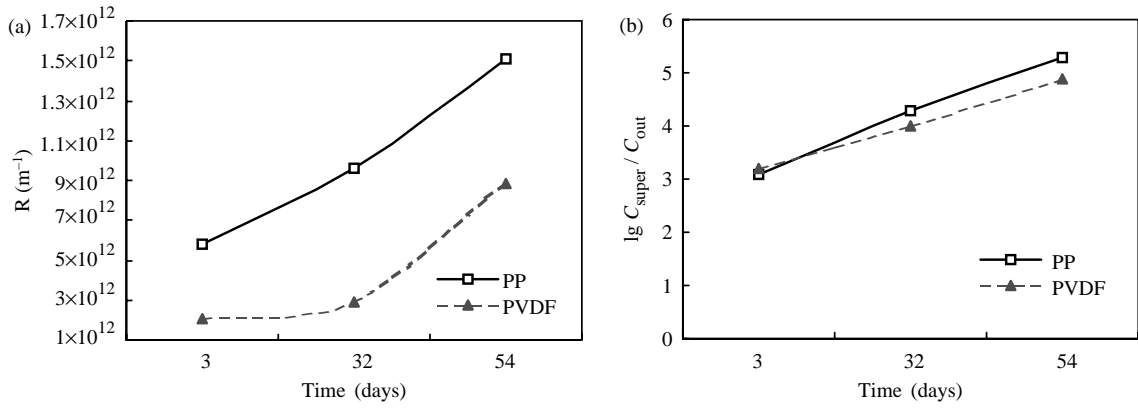

Figure 4 The test results during the operation; (a) Filtration resistance; (b) Virus rejection 
removal cannot reach the maximum since the membrane flux should maintain at an economical value in this test.

In order to confirm the virus rejection mechanisms of the MBR, after the 66 days operation, the membrane modules were immersed in the solutions with $0.7 \%$ sodium hydroxide and $2 \%$ sodium hypochlorite for 12 hours to remove the dynamic layer closely absorbed on the membrane fibers. Thereafter, the modules were reset in the system and a certain concentration of coliphage $\mathrm{f} 2$ was fed to the system. After chemical cleaning, the membrane resistance of PVDF decreased from $7.9 \times 10^{12}$ to $8.5 \times 10^{11}$, and the corresponding $\mathrm{LRV}_{\mathrm{m}}$ decreased sharply from 3.9 to $0.8 \mathrm{logs}$ when virus concentrations in the supernatant was 5.1 logs. These results proved that the dynamic layer plays an important role in rejecting virus.

\section{Impact of feed virus concentration}

Variations of feed virus concentrations may impact the virus quantity in the efferent and the $\mathrm{LRV}_{\mathrm{m}}$ in the first 20-day operation. Figure 5 illustrates the relationship between the supernatant and effluent virus levels under a low membrane resistance condition. The virus quantity in the effluent increased with the virus concentration in the supernatant. This result showed that the pore size of the dynamic layer was larger than the size of the virus at the low membrane resistance.

However, the $\mathrm{LRV}_{\mathrm{m}}$ achieved by the two MF membranes were relatively stable (Figure 6). The $\mathrm{LRV}_{\mathrm{m}}$ was independent of the supernatant virus concentration when it was relatively low (lower than $5 \times 10^{5} \mathrm{PFU} / \mathrm{mL}$ ), but it increased slightly when virus levels in the feed increased beyond $10^{8} \mathrm{PFU} / \mathrm{mL}$.

\section{Virus inactivation in different system}

The persistence of coliphage $\mathrm{f} 2$ was determined by exposing it to activated sludge (A), aerated clean water (B) and non-aerated clean water (C) systems, respectively, in order to mimic the natural state of viruses in the environment. Figure 7 depicted the effect of the virus inactivation in three different systems at nearly the same temperature $\left(24 \pm 1^{\circ} \mathrm{C}\right)$.

When the coliphage $\mathrm{f} 2$ exposed in a clean water system without aeration, the virus titers remained without significant reduction until the end of the experiments. The virus inactivation progressed clearly faster under the aerated condition than under the non-aerated condition, either in the activated sludge system or in the clean water

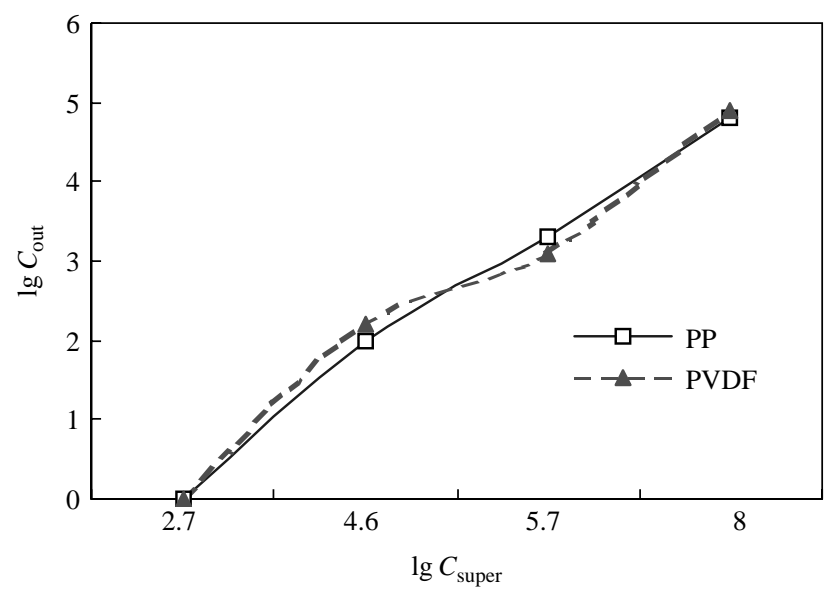

Figure 5 Test of virus passage membrane at low membrane resistance $\left(R_{P P}=6.5 \times 10^{12}\right.$; RPVDF $=2.4 \times 10^{12}$ ) 


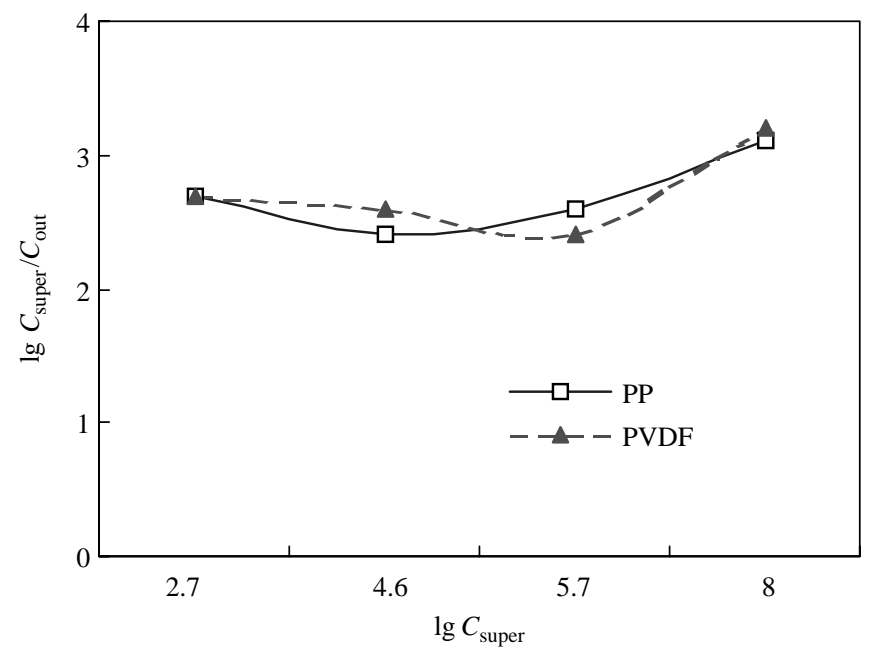

Figure $6 \mathrm{LRV}_{\mathrm{m}}$ at different feed virus concentration

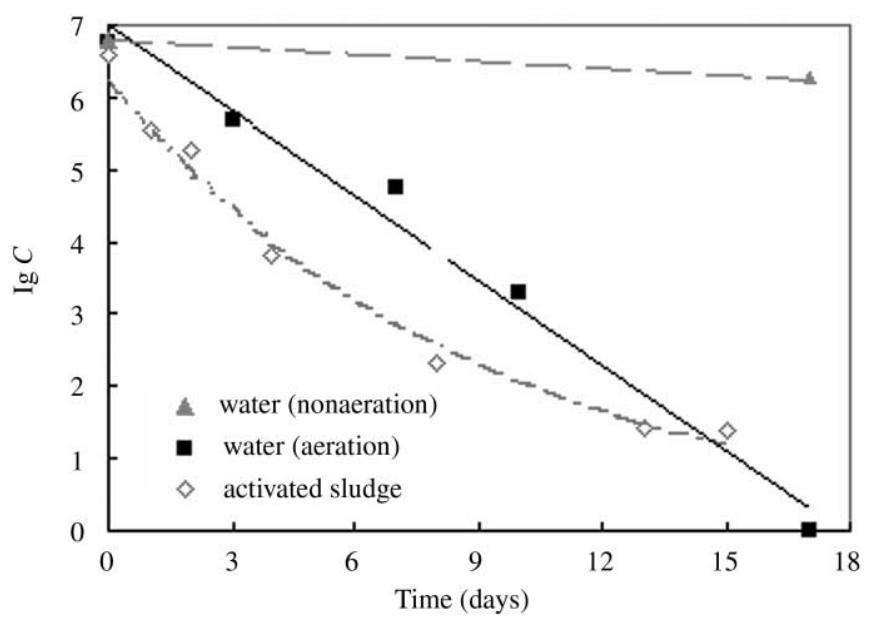

Figure 7 Results of virus inactivation in different systems

system. A possible explanation is the presence of the air-water interface (AWI). Previous work has shown that shaking viral suspensions or exposing viruses to the AWI may lead to inactivation of virus particles (Thompson et al., 1998), suggesting that viruses in a solution could approach the AWI via convection and diffusion and are absorbed and inactivated subsequently at the AWI by the forces deforming the virus particles. Therefore, the AWI can be continuously regenerated to provide a renewed location for virus inactivation by shaking the virus suspension.

The effect of microbial activity on virus survival was observed in the activated sludge and clean water of the MBR under an aeration condition (Figure 7). The inactivation of the coliphage $\mathrm{f} 2$ was more rapid in the activated sludge than in the clean water, showing that the microbial activity is an important factor in the viral inactivation.

\section{Conclusions}

Viruses can be effectively removed by the MBR with the gravity drain. During the stable operation, the MBR achieved an overall virus removal rate of 2.6-5.1 logs. No significant difference was observed in the virus rejection between the PP and PVDF 
membrane modules. The dynamic layer on the membrane surface plays an important role in the rejection of virus in the MBR. It was found that aeration could clearly reduce the viruses, which was more rapid in the activated sludge than in the clean water. The microbial activity is also an important factor affecting the viral inactivation.

\section{Acknowledgements}

This study is financially supported by the National Nature Science Foundation of China (No. 50538090).

\section{References}

Gunder, B. and Krauth, K. (1998). Replacement of secondary clarification by membrane separation - results with plate and hollow fibre modules. Water Science and Technology, 38(4-5), 383-393.

Hu, J.Y., Ong, S.L., Song, L.F., Feng, Y.Y., Liu, W.T., Tan, T.W., Lee, L.Y. and Ng, W.J. (2003). Removal of MS2 bacteriophage using membrane technologies. Water Science and Technology, 47(12), $163-168$.

Krauth, K. and Staab, K.F. (1993). Pressurized bioreactor with membrane separation for wastewater treatment. Water Research, 27, 405-411.

Madaeni, S.S. (1995). Virus removal for water and wastewater using membranes. Journal of Membrane Science, 102, 65-75.

Pesaro, F., Sorg, I. and Metzler, A. (1995). In situ inactivation of animal viruses and a coliphage in nonaerated liquid and semiliquid animal wastes. Applied and Environmental Microbiology, 61(1), 92-97.

Petterson, S.R. and Ashbolt, N.J. (2001). Viral risks associated with wastewater reuse: modeling virus persistence on wastewater irrigated salad crops. Water Science and Technology, 43(12), 23-26.

Rzezutka, A. and Cook, N. (2004). Survival of human enteric viruses in the environment and food. FEMS Microbiology Reviews, 28, 441-453.

Sakoda, A., Sakai, Y., Hayakawa, K., et al. (1997). Adsorption of viruses in water environment onto solid surfaces. Water Science and Technology, 35(7), 107-114.

Salgot, M., Campos, C. and Galofré, B. (2001). Biological control tools for wastewater reclamation and reuse. A critical review. Water Science and Technology, 43(10), 195-201.

Shang, C., Wong, H.M. and Chen, G.H. (2005). Bacteriophage MS-2 removal by submerged membrane bioreactor. Water Research, 39, 4211-4219.

Steven, W.T., Judd, S.J. and Mcloughlin, B. (1998). Reduction of faecal coliform bacteria in sewage effluents using a microporous polymeric membrane. Water Research, 32, 1417-1422.

Thompson, S.S., Flury, M., Yates, M.V. and Jury, W.A. (1998). Role of the air-water-solid interface in bacteriophage sorption experiments. Applied and Environmental Microbiology, 64(1), 304-309.

Ueda, T. and Horan, N.J. (2000). Fate of indigenous bacteriophage in a membrane bioreactor. Water Research, 34, 2151-2159.

Zheng, X., Lu, W.Z., Yang, M. and Liu, J.X. (2005). Evaluation of virus removal in MBR using coliphages T4. Chinese Science Bulletin, 50(9), 862-867. 